\title{
Developing an intervention course to promote students' well-being and studying in university context
}

Henna Asikainen ( $\nabla$ henna.asikainen@helsinki.fi )

University of Helsinki: Helsingin Yliopisto https://orcid.org/0000-0002-3858-211X

Nina Katajavuori

University of Helsinki: Helsingin Yliopisto

\section{Case study}

Keywords: Approaches to learning, psychological flexibility, well-being, online intervention tool, peer support, reflection

Posted Date: October 12th, 2020

DOI: https://doi.org/10.21203/rs.3.rs-88092/v1

License: (c) (i) This work is licensed under a Creative Commons Attribution 4.0 International License.

Read Full License 


\title{
Developing an intervention course to promote students' well-being and studying in university context
}

\author{
Abstract \\ Background: The purpose of this paper was to build an intervention course for university \\ students which promotes both students' well-being as well as their learning and study skills. \\ Research has shown that psychological flexibility has a great effect on well-being as well as \\ studying in higher education \\ Case presentation: The basis of our intervention course is to promote psychological flexibility \\ and students' study skills with the help of peer support and reflection. \\ Conclusions: We argue that an online, 8-week intervention course, which promotes both \\ student well-being and their study skills, is a good way to support students in higher education \\ and both aspects should be taken into account when supporting university students.
}

Keywords: Approaches to learning, psychological flexibility, well-being, online intervention toel, peer support, reflection

\section{Background}

The decline in well-being and increased mental disorders experienced by higher education students have become a serious issue around the world [1-3]. In the United States, over $50 \%$ of college students have a psychiatric disorder and over $60 \%$ have experienced serious anxiety [4]. In Finland, one-third of students have experienced mental problems [5]. At the same time, there has 
been an increase in student dropout rates and study times have increased. As in most European countries, also in Finland, three important aims to solve this problem have been added to the agenda: students' completion of degrees, completion in a reasonable period, and reducing student dropout [6]. In addition, the demands of today's workforce life require excellent life-long learning skills from students and the ability to solve complex and multidisciplinary problems under heavy workloads and stress. Thus, there is a huge discrepancy between the demands set for students and students' well-being.

It has been stated that the transition to university is a particularly challenging time for students, because it coincides with the transition to adulthood, and has been shown to be stressful and disruptive for students [7]. During this time students face new challenges and increased responsibilities; young people are moving away from the family home and are exploring their identity in academic and social domains and taking personal responsibility for their own decision making [8]. This transition has been shown to be characterised by steep declines in psychological well-being, cognitive-affective strengths, and social well-being as well as increases in psychological distress and cognitive-affective vulnerabilities [7]. Thus, students' distress is already present from the beginning of their time at university and it has been shown that wellbeing can get worse as they proceed [9].

Despite of the evidence of poor well-being among students, problems related to students' wellbeing and their effect on learning have not been sufficiently taken into consideration in curriculum development. There is a need for services which would enhance students' well-being, especially in the early stages, due to the transition challenges being faced [7]. A growing body of evidence demonstrates that social and emotional skills affect greatly academic performance [10] and students' studying, and learning is related to their well-being [11]. Furthermore, there is also 
evidence that many students encounter troubles in their learning and studying processes [12, 13] and in higher education, the emphasis should also be paid to supporting students by considering both their well-being as well as their study skills and life-long learning skills [e.g. 14]. Thus, effective ways to support students' well-being and their ability to study are highly needed.

Our aim with this paper is to describe a course that was developed to support students' well-being as well as their study skills at university. This course was based on fostering students' psychological flexibility and study skills, and peer support and reflection were chosen as the central pedagogical tools to support the development of these aspects.

\section{Theoretical aspects}

Well-being is not easy to define because there are many definitions and traditions and things to consider when thinking about well-being [15]. The World Health Organization [16, p.12] has defined wellbeing as: " a state of well-being in which every individual realizes his or her own potential, can cope with the normal stresses of life, can work productively and fruitfully, and is able to make a contribution to her or his community." Health is also seen as a holistic way as "a state of complete physical, mental and social well-being and not merely the absence of disease or infirmity." Traditionally, subjective well-being can be divided to two traditions: the hedonic (feeling good about or having positive emotions toward one's life) and the eudaimonic (functioning well in life as an individual) [17]. The hedonic tradition focuses on emotional wellbeing and eudaimonia tradition focuses on psychological and social well-being. Thus, one prominent model of wellbeing defines wellbeing as having these three parts [18]: emotional wellbeing, psychological well-being, and social well-being. Emotional well-being can be described as

positive emotions towards life or good satisfaction in life. Psychological well-being relates to how 
individuals view themselves as functioning in life and it can be conceptualised though processes such as self-acceptance, sense of mastery and competence, positive relationships with others, feeling of personal growth or development, sense of goal-directedness in life and autonomy [19]. In addition to psychological well-being, social well-being also refers to positive functioning but from a social perspective and it can be understood from five dimensions: social coherence, social acceptance, social actualization, social contribution, and social integration [20]. Social coherence refers to perceptions of the quality and understanding of the social world around and social integration refers to the evaluation of the quality of the role one has in society or their belonging to the social community [20]. Social contribution means the value that the individual has to offer to the social community and social actualisation refers to the valued potential that the society has to offer in means of valuing and recognising the society's potential [20]. Social acceptance refers to acceptance and trustfulness in others in society, a.k.a. a belief of other people's kindness [20].

Research has shown that one influential predictor of well-being is psychological flexibility [2123]. Psychological flexibility describes people's ability to be connected with the present and regulate their emotions and actions despite the unpleasant feelings or thoughts they might have $[23,24]$ and further, to take value-based actions. It is the opposite concept to experimental avoidance which emphasises efforts to alter or avoid negative private events, such as emotions, thoughts or bodily sensations, despite the negative consequences or personal harm such efforts to avoid might have [25]. Experimental avoidance is harmful for well-being as it has been shown to be strongly correlated with general psychopathology, anxiety and depression and results to unpleasant thoughts and feelings and disconnecting from oneself [24,27].

On the contrary, people with high psychological flexibility act according to their own values and accept their negative thoughts, emotions and sensations rather than avoid them, and deal with these 
negative emotions and thoughts by opening up to them and observing them from another perspective mindfully [28]. The origin of psychological flexibility lies in acceptance and commitment therapy (ACT) [23] and is based on the ACT theory of psychopathology. ACT is a part of the "third wave" of the cognitive based therapies (CBT) which emphasise the evidencebased process of the individual, comprising the identification of change processes which support the psychological development of the individual $[22,25]$. Psychological flexibility is the core process which is developed in ACT therapy [23].

Psychological flexibility is established through six overlapping core processes which are strengthened in ACT. These core processes are acceptance, cognitive diffusion, being present, self as context, values and committed action [23]. Acceptance is the opposite of experimental avoidance and means “the active embrace of those private events occasioned by one's history without unnecessary attempts to change their frequency of form" [23, p.7]. Acceptance is not a matter of tolerance but rather it supports value-based action and exploration of feelings, memories and thoughts from an observer perspective [29]. Cognitive defusion represents the process or techniques through which one's relationship to these negative thoughts is altered and the ability to look at one's own thoughts as separate parts of internal behaviour, and not consider them to be truth about the world or oneself [30]. Being present relates to continuous contact with a range of events or thoughts as they occur, emphasising the on-going process of defused and nonjudgemental description of thoughts [23]. Being present comprises seeing oneself as a context or a container of one's experiences and thoughts, and thus, seeing these thoughts as being separate from the self [22]. Values are also an important part of psychological flexibility as they offer guidance in terms of what behaviours are likely to lead to long-term satisfaction and experience of meaningfulness in life, an explicit aim in ACT [23]. The sixth aspect of flexibility, committed 
action, leads to a value-emphasised life through taking value-based action, instead of action motivated by avoidance of negative thoughts [23].

Promoting psychological flexibility has been shown to improve all aspects of wellbeing: emotional, psychological and social well-being [23,31]. It is related also to physical well-being as it is negatively related to experiences of for example sleeping problems [32] and eating disorders [33]. Thus, when people are more open and accept their emotional experiences and engage and persist in activities which are in line with their values, they have a possibility to gain a rich and meaningful life straightaway [34]. Enhancing value-based actions by allocating time to important life domains has been shown to influence many aspects of wellbeing such as life satisfaction, frequent positive emotions and the ability to meet needs of belonging, competence, and autonomy [35]. Furthermore, research and meta-analyses have shown that psychological flexibility been shown to reduce depression and anxiety [36,37] and has been found to have a central role in stress management [38] and life management [27]. Many ACT-based interventions have been conducted around the world and they have been shown to be effective in treatment number of conditions including low quality of life, stress management and well-being $[39,40]$. It has been also shown to have a central role in improving performance, well-being and results in the workplace [41-42].

Some efforts for improving psychological flexibility based on the principles of ACT have been made in higher education and they have shown to be successful in improving students' well-being and stress levels [31, 43, 44, 45] as well as their psychological flexibility [31]. Psychological flexibility has shown to be related to proceeding of the studies as a study by Asikainen et al. [46] showed that psychological flexibility is positively related to positive emotions in learning as well as study progression. It has also been shown to be positively related to integration into studying at university as well as study progression [47]. Recent pilot studies have alse indicated that the theory 
of psychological flexibility is the core process in explaining procrastination in the higher education context $[48,49]$. Furthermore, psychological flexibility has alse been shown to be related to students' self-regulation in learning $[47,50]$, and it has also been shown to be particularly important for students who are at higher risk of academic failure [51]. Thus, the importance of psychological flexibility is evident in the university context. The number of interventions aiming to improve psychological flexibility with ATC is growing but most of the studies relate mainly to occasional interventions or are included in student counselling. In addition, these interventions are not part of curriculums. Thus, there is a need to develop interventions, which are included in study programs and which aim to improve students' psychological flexibility.

\section{Quality of learning and studying at the university}

The importance of the quality of learning and studying in higher education have been clearly shown in research, indicating that learning and studying processes are related to students' wellbeing and study progression [11]. One way to conceptualise students' learning and studying

processes is the SAL (students' approaches to learning) tradition [52, 53]. Students' approaches to learning are traditionally differentiated into two different ways of learning: the surface and deep approaches to learning $[52,53,54]$. The deep approach to learning is associated with students' quest to understand and to engage appropriately in meaningful learning, focusing on the main principles and using strategies that are appropriate for creating such meaning. The surface approach to learning, on the other hand, refers to students selectively memorising, based on motives or intentions that are extrinsic to the real purpose of the task, such as a fear of failure or keeping out of trouble [55]. The traditions also recognise a third slightly different approach, namely organised studying [56] which emphasises time management and effort in studying [46]. 
Research has shown that the deep approach to learning is related to better learning outcomes [57, 58]. However recent research has pointed out that the deep approach to learning is not enough if the students are not organised in their studying $[13,59]$. Recent research has emphasised the important role of organised studying as it has been shown to be central in success at university [60, $61,62]$. It is also possible to promote students' time-management skills through interventions in which students learn and practise organisational skills [63,64]. Furthermore, research has shown that students' approaches to learning are related to students' well-being at the university showing that poor study skills can lead to a risk of study-related burnout in studies [11]. As stated above, time allocation to important activities is a central part in achieving a meaningful life [34]. For these reasons, it would be important to support students' time management skills in order to improve their studying as well as to help students to allocate time better to things that are important to them. In addition, as deep approach to learning is related to better achievement as well as better wellbeing, it is utmost important to enhance both students time management skills as well as their deep-level learning.

\section{Online interventions}

Online interventions have been identified as cost-effective and efficient ways to provide support for university students; they are easy to access, and they have shown to be effective in promoting students' mental health and well-being $[65,66]$. A comparison in a meta-analysis between faceto-face and internet intervention revealed no differences in effectiveness, and thus, strong support has been brought up for the adoption of online psychological interventions [65]. In addition, ACTbased interventions have been successfully carried out in a blended learning environment, in which students do the exercises online but still have face-to-face meetings [31]. Interventions which have been carried out solely for higher education students show that with a web-based programme, it is 
possible to improve students' well-being and life satisfaction and reduce depression and anxiety $[31,38,44,67]$. Furthermore, research has been conducted on the development of study skills in online courses. Studies have shown that online courses can support the development of alternative study skills $[68,69]$. Thus, our intervention course was developed as an online course in order to offer the course to a wide range of students.

\section{Case presentation}

Next, we present the central pedagogical tools which we emphasise in the improvement of wellbeing and studying among university students: peer support and reflection. These were chosen to foster the development of psychological flexibility and students' study processes.

\section{Peer support}

Peer support has been found to be important in learning and studying. Research has shown that peer support is related to successful study progression and it is a central factor enhancing studying at university [62]. In addition, peer support has been shown to deepen student learning [70], and to be positively related to students' positive experiences of teaching as well as the deep approach to learning, and negatively related to the surface approach to learning [71]. Peer support has also been found to be important in increasing well-being. Peer support can be defined as a "system of giving and receiving help founded on key principles of respect, shared responsibility, and mutual agreement of what is helpful" $[72$, p. 6]. Peer support can help students who are experiencing negative emotions, to comprehend someone else's situation empathically through the shared experiences and find a connection with each other [72]. However, there is evidence that around $50 \%$ of students do not talk to anyone about their mental health when distressed [73]. In addition, 
the benefits of peer support in different interventions enhancing different aspects of mental health has been widely shown [74]. Thus, peer support can be regarded an important element in supporting both well-being as well as learning and studying. Thus, it would be important that peer support would be implemented to courses in higher education due to its positive effects for students' well-being and possibilities for enhancing learning.

\section{Reflection}

Reflection plays a central role in learning, and thus, reflective practices could be important tools to improve the development of psychological flexibility, and to help students to develop their studying practices. It has been shown that reflection supports learning, and deeper and critical reflection is related to deeper learning, and further, to better learning outcomes [75]. Students can learn to reflect on their thoughts, beliefs and practices, and furthermore, also feelings and emotions [76, 77, 78]. In the development of psychological flexibility becoming aware of, and further, exploration of one's thought, beliefs and taken-for-granted attitudes is important. Reflection can foster this learning. Not all reflection is however critical, but deep reflection may lead to better learning including transformative learning; meaning changes in one's behaviour [78]. For this reason, it is important that students' reflective practice is guided and supported by teachers. Students could be guided to practise self-reflection, meaning that they explore and challenge their personal values and assumptions and question their core beliefs, which all are features of critical reflection $[77,79]$. This, in turn, may lead to a change in one's beliefs, actions and values; which is also known as transformative learning [80]. When fixed assumptions and taken-for-granted attitudes, expectations, judgements, habits of mind, and mindsets are reflected and made more open, it is also possible to find new ways to think and to take actions, and to realise that some judgements, thoughts and interpretations have greater validity than others [80]. Thus, reflection on 
one's thoughts and experience provide a link to praxis [78] and can be regarded as a function which is central also in the process of psychological flexibility where taking another perspective to thoughts and feelings is central.

Reflection may be engaged from several perspectives. Drawing on multiple perspectives provides the student with a holistic understanding of their thoughts, feelings, or the practices they are working on [78]. The aim of fostering psychological flexibility is to help students to be able to monitor themselves, and thus, fostering students' reflective practice could enhance the development of psychological flexibility. Reflection can be fostered by reflective work, which is likely to be represented in a written form, which can be seen by others and to be assessed. These factors may foster the quality of reflection [76]. Feedback on written work can be used as a vehicle for reflection, and thus, foster students' skills in reflecting on themselves [81].

To sum up, our aim in this course is to support students successful studying by supporting different aspects of wellbeing (physical, emotional, social and psychological) as well as students study skills (see Figure 1). The central process to support these aims is to support the development of psychological flexibility as it has been shown to have positive effects on all aspects of wellbeing as well as learning and studying in higher education. The central pedagogical tools, which we have chosen to support these aspects are reflection one's own thoughts through different assignments and peer support and feedback which takes place by working in peer groups and giving and receiving feedback from other students. 


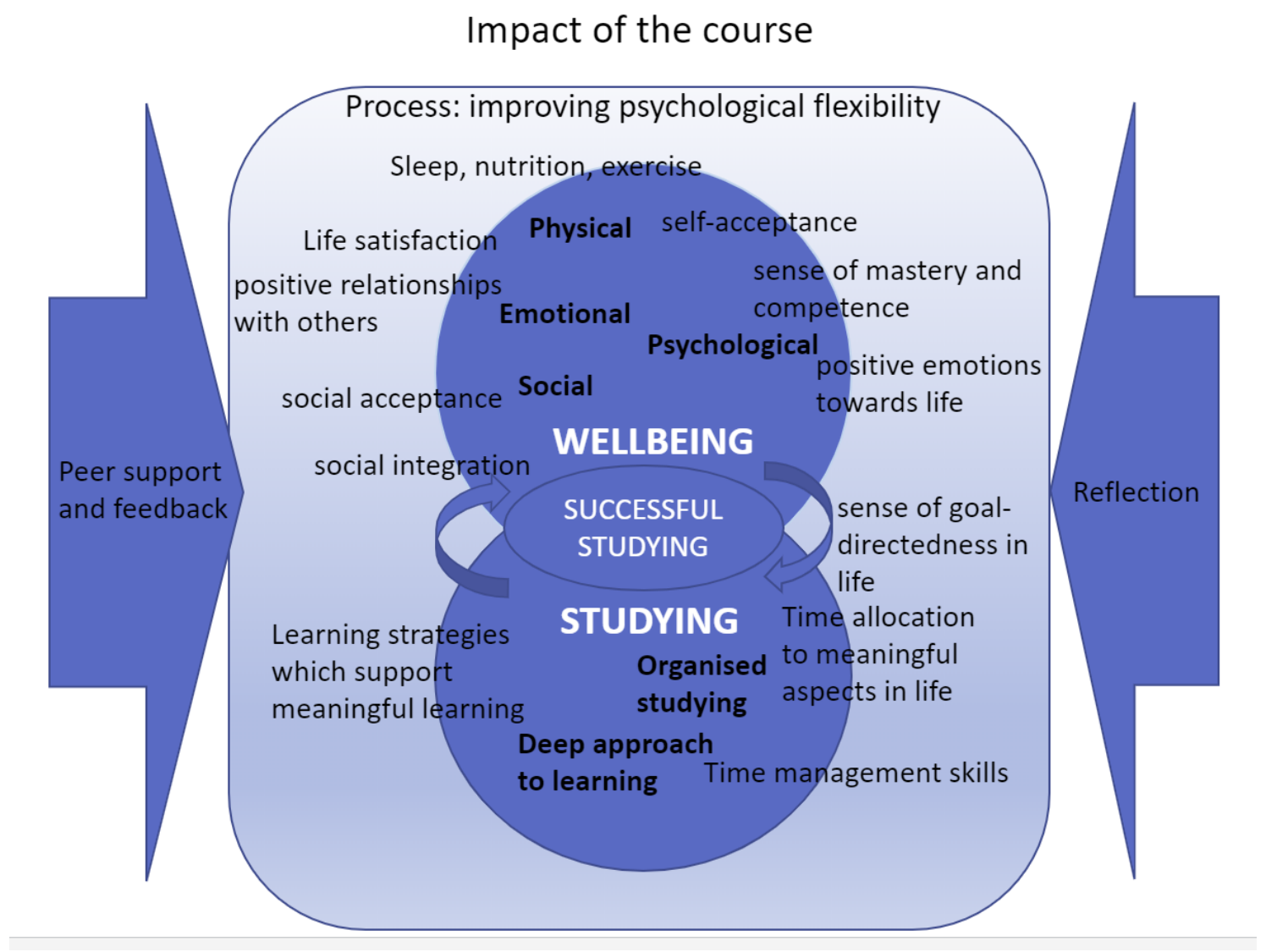

Figure 1. Impact of the course

\section{Intervention course}

An optional 8-week web-based course was developed for university students to improve their wellbeing, stress-management, psychological flexibility and study skills (see Figure 2). To achieve these aims, reflective practices as well as peer support and feedback are implemented in the course. Students who complete this course are awarded 3 ECTS. The course has been built on the Moodle online platform. This course was designed so that students do independently weekly exercises, reflect the themes of the course in small groups and give and receive peer feedback of each other's assignments. The course is suitable for all students in different levels of studies and can be easily implemented to curricula. Teacher's role in this course is to facilitate students' progress during the 
course and monitor the group discussions and students' assignments. The teachers also meet the students online in the course and give video instructions to the module's themes and assignments.

Reflective practice in using this intervention tool

Reflection has a central role during this course. Each week includes assignments in which students reflect the themes and practices of the week. In the reflections, students are asked to write about the exercises they did during the week and what they had learnt from them, and further, how these exercises have affected their studying and well-being. Students also write a final learning journal which covers the whole course and they are asked to think how this course affects their well-being and studying.

Peer support in this intervention course

Peer support has a central role in this online intervention course. In the course, students are divided to small groups in the beginning of the course and they study together in these groups throughout the course reflecting together the themes and assignments of each modules. Students also give peer feedback of the final reflection journal for two students in the end of the course. Students are instructed to give positive and encouraging feedback to each other.

Next, the modules of the intervention tool are presented in more detail (See Figure 2).

\section{Modules of the intervention course}

This intervention course consists of eight modules, each week lasting for one week (see Figure 2). They include video and text introductions to the themes of the week, individual experimental and reflective exercises in which participants are asked to write down their experiences and reflections. 
In addition, small group discussions about the themes are held every week. Next, we present these modules in more detail.

\begin{tabular}{|c|c|c|c|c|c|c|c|}
\hline $\begin{array}{l}\text { Introduction } \\
\text { Module }\end{array}$ & Module 1 & Module 2 & Module 3 & Module 4 & Module 5 & Module 6 & Module 7 \\
\hline $\begin{array}{l}\text { Introduction } \\
\text { to the course } \\
\text { and themes }\end{array}$ & $\begin{array}{l}\text { THEME } \\
\text { What is } \\
\text { important: }\end{array}$ & $\begin{array}{l}\text { THEME } \\
\text { Focusing on } \\
\text { the present: }\end{array}$ & $\begin{array}{l}\text { THEME } \\
\text { Power of } \\
\text { thoughts : }\end{array}$ & $\begin{array}{l}\text { THEME } \\
\text { Coping with } \\
\text { studying: }\end{array}$ & $\begin{array}{l}\text { THEME } \\
\text { Acceptance } \\
\text { and self- }\end{array}$ & $\begin{array}{l}\text { THEME } \\
\text { Acceptance } \\
\text { and self- }\end{array}$ & $\begin{array}{c}\text { Evaluation of } \\
\text { wellbeing and } \\
\text { studying }\end{array}$ \\
\hline $\begin{array}{c}\text { Evaluation of } \\
\text { wellbeing and } \\
\text { studying }\end{array}$ & $\begin{array}{l}\text { Individual } \\
\text { assignments, } \\
\text { setting a goal }\end{array}$ & $\begin{array}{c}\text { Individual } \\
\text { assignments }\end{array}$ & $\begin{array}{l}\text { Individual } \\
\text { assignments + } \\
\text { online meeting }\end{array}$ & $\begin{array}{c}\text { Individual } \\
\text { assignments }\end{array}$ & $\begin{array}{l}\text { compassion: } \\
\text { Individual } \\
\text { assignments }\end{array}$ & $\begin{array}{l}\text { compassion: } \\
\text { Individual } \\
\text { assignments }\end{array}$ & $\begin{array}{l}\text { Final learning } \\
\text { report }+ \\
\text { individual } \\
\text { feedback from } \\
\text { peers }\end{array}$ \\
\hline $\begin{array}{l}\text { Start of peer } \\
\text { group work }\end{array}$ & $\begin{array}{l}\text { Group } \\
\text { discussion and } \\
\text { reflection }\end{array}$ & $\begin{array}{l}\text { Group } \\
\text { discussion and } \\
\text { reflection }\end{array}$ & $\begin{array}{l}\text { Group } \\
\text { discussion and } \\
\text { reflection }\end{array}$ & $\begin{array}{l}\text { Group } \\
\text { reflection } \\
\text { assignment }\end{array}$ & $\begin{array}{c}\text { Group } \\
\text { discussion and } \\
\text { feedback }\end{array}$ & $\begin{array}{l}\text { Group } \\
\text { discussion and } \\
\text { reflection }\end{array}$ & $\begin{array}{l}\text { Group } \\
\text { discussion and } \\
\text { reflection }\end{array}$ \\
\hline
\end{tabular}

Figure 2. Design of the course

The Introduction module includes video introductions to the course and an introduction to the central theme of the course: psychological flexibility and well-being. This module also includes all the practical information about course assignments and completing the course, including deadlines and guidelines for group work and giving peer feedback. To help students to reflect on their well-being and studying, students evaluate their level of well-being and their time management skills at the beginning of the course based on validated questionnaires. For example, students get feedback about their risk of study-related burnout and receive feedback and guidance according to the result they get. The same evaluations are also completed at the end of the course and then, the students reflect on the change in their well-being and study skills based on their scores before and after the course. The aim of this is to increase students' understanding of their own condition and how to affect to it, to engage the students to this course and its assignments. During this first module students are also offered to do simple exercises on promoting 
psychological flexibility and they start a time management assignment in which they are asked to monitor and record their time-usage for a week. The aim of this task is to help students to become aware of their time-usage and help them in the forthcoming assignments during this course. In addition, the students also start the group work by introducing themselves to the peer group and sharing thoughts about the start of the course.

The theme of the first module is What is important. This module consists of material and exercises related to one's values. In this module, there is first introductions to values and why they are important. In addition, students do exercises which help them to think about and clarify issues that are important to them in their life. For example, students are asked to think about themselves far into the future having lived a very good life and are asked to think about the things they could remember about their lives, what they valued. In addition, students are asked to think about several areas of life, like well-being, family, friends and to think about what is important for them and what could they do to foster this value. After these exercises, students also set a value-based goal which they would want to achieve, and this goal is revisited and monitored during the course. To help the students to reflect on how their values are manifested in their life, students have a group discussion where they reflect their thoughts about the time-management task and how could time management help with the achievement of the goal.

The theme of the second module is Focusing on the present. In this module, introductions are given to what being present really means and why it is important. In addition, introductions to what brain research tell us about focusing and being present, and how to foster one's learning are given. The exercises in this week consists of practicing being present mindfully and intentionally. These exercises include for example asking students to do something mindfully by paying attention to this situation (waiting for a bus, eating...) or just trying to focus on the present moment. Students 
are also instructed to be intentionally present and listening when communicating with a peer. This module includes also breathing and relaxation exercises. Students are asked to test different kind of short exercises during the day and monitor, how these exercises affect to their wellbeing. A small group discussion is also included. Students are asked to share their experiences of the exercises of the week and how they have affected to their studying and wellbeing, and further, how these exercises could help them to achieve their goal.

The third module is related to the theme Power of the thoughts. First, introductions are given to thoughts, how powerful they are, how they are related to emotions, and why it is important to become conscious of one's thoughts. Students also watch a video about feelings and emotions, how they are developed and how we interpret the message of our emotions. With different exercises students are encouraged to become conscious of their thoughts, to explore and test these thoughts, and to look at their thoughts just as thoughts and not facts or truths about themselves or the current situations. For example, students are instructed to think about their negative thoughts just as thoughts which are like floating leaves on a flowing river: they can be observed, and they come and go. In addition, students are for example asked to find new alternative thoughts and think of the long-term effects of these different thoughts to their behaviour and well-being. These exercises aim to help the students to change their relationship with the negative thoughts they might have. Students also share their experiences and discoveries in small groups and further, they are asked to think of how becoming aware and accepting their thoughts can help them to achieve their goals regarding studying and wellbeing. During this week students also meet the teachers of the course online and discuss about the themes and questions of the course together with students.

The fourth module consists of exercises which are comprehensively related to the theme Coping with studying. This module consists of introductions to this theme, web-lectures and assignments 
regarding studying and study techniques, the significance of physical exercise, sleep, and nutrition in order to make studying and learning more effective. During this module, students are encouraged to think of their life habits (including sleeping, exercise and nutrition) in order to reinforce the value-based actions related to these themes. Students are encouraged to test and monitor how doing some physical exercises or investing more time to sleeping would affect to their general well-being and study energy. In this module students are also asked to identify the issues and elements which contradict the student's own values related to studying or general lifehabits. In addition, this week includes an introduction to learning and study techniques. Students are encouraged to apply these techniques to their learning and studying and to monitor which techniques and which practices would work best for them. During this week, students discuss in their peer groups and write a group reflection about their experiences about this week's topics.

The fifth module is related to the theme Acceptance and self-compassion. This module consists of introduction to this theme, web-lectures about self-compassion and individual and group assignments. In this module, students continue with exercises and techniques which help them to accept, confront and explore their thoughts. For example, they are asked to practise acceptance of the past as well as becoming aware of which things they can and cannot affect. This module includes also self-compassion exercises. Students are for example asked to monitor how they speak to themselves, what kind of thoughts they have towards themselves and practice more compassionate towards themselves. Students are also asked to take thankful attitude towards their life, and further, to observe how this kind of behaviour affects to their well-being and studying. Furthermore, during this week, the peer groups give feedback about the group reflections two one other group. 
Module six is related to Committed actions. This module consists of introduction to this theme, web-lecture about the significance of taken committed, value-based actions. Students are encouraged to become conscious of obstacles which hinder them to take value-based actions and further, they practice engage to these actions in order to help them to gain their goals which are set up in the beginning of the course. During this module students are for example asked to practice decision-making by analysing different alternative choices and short- and long-term effects in the situation, and further, by monitoring their decision-making for a week. Students are also asked think of how they could commit to take actions which help them to go towards important things in their studying in the future as well. In the end of the week students discuss in their peer groups about their experiences and ideas of how to enhance taking value-based committed actions.

The module 7 is a Concluding module. Students write a final learning journal in which they reflect on their learning and experiences of the effects of the course on their studying and well-being, and further, they analyse how they have proceeded with the goal they have set up in the beginning of the course. Students evaluate their well-being and studying based on the questionnaires again and are encouraged to analyse the change in their well-being and studying during the course. Students also give individual constructive feedback of the reflective journals to two other students anonymously, and further, students have a final, peer group discussion where they share their experiences of the course including which exercises have been most effective to them and why.

\section{Discussion and conclusions}

Our aim was to develop a pedagogically reasonable and beneficial web-based course to support students' well-being as well as their study skills at university. Poor well-being of university students is a common concern worldwide, and effective tools and practices to increase students' 
well-being are needed. We designed the intervention course to equip students with tools to enhance their well-being and also to help them to develop their study skills, because well-being should be also taken into account when fostering students learning and studying [11, 51, 82]. This course was based on the idea of fostering psychological flexibility, which has convincingly been shown to be an essential factor in improving psychological, social and emotional as well as physical wellbeing in many ways $[38,45,82]$.

In the course, we focused on the thinking about and clarifying students' values as well as taking value-based action. Values are the foundation for fostering psychological flexibility and valuebased action and behaviour is necessary to life satisfaction and experience of meaningful life [29, 83] In order to experience life-satisfaction, life should involve action, purpose, direction and orientation towards doing something that matters. Yet often these meanings and purposes are not adequately considered or recognised, which may lead to losing one's values [83]. Therefore, considering one's values help in orientating and taking meaningful actions, because values are not goals to be achieved, but the things one wants to move toward [83]. Thus, clarifying one's values and supporting value-based action during this intervention course is one of the most essential parts of the course and gives the basis for further exercises.

We also concentrated on the mindful presence and concentration during the intervention course. Breathing and relaxation exercises have been shown to be effective in reducing stress and increasing wellbeing, and further, to be potential self-care strategies for students to implement to their studies [84]. It has been also shown that combining physical exercise to relaxation is an effective strategy to reduce stress [85]. In addition, auto-piloting, like doing and thinking without thinking about it, may easily lead to a life which is against one's values [22, 83]. Attending to the present moment may provide opportunities to learn from a current experience and to see new 
options for actions. The present moment is when learning occurs and when one's values are lived [83]. The core of psychological flexibility is to be in contact with the present, with different events and thoughts as they occur, without judging them [23, 83]. Both relaxation and being mindfully and intentionally present have been shown to be effective in improving subjective wellbeing [87]. For these reasons, our course includes exercises related to these themes and students are asked to monitor how these exercises affect to their well-being and studying.

The exercises also concentrated on the power of thoughts. This is related to one of the central process of defusion, in which one's reaction to negative thoughts is altered by the ability to see thoughts as a product of the mind and not as a truth about the world or oneself [22, 30]. It has been stated that cognitive defusion is the central process in psychological flexibility and is central in explaining changes in well-being [87]. In addition, cognitive defusion is also parallel to the process of acceptance which means that negative thoughts and feelings are actively embraced and not unnecessarily changed [23]. Exercises in the course help the students to develop their psychological flexibility by looking at their own thoughts as separate parts of their behaviour, and to help them to see their thoughts just as thoughts rather than as truths $[30,73]$. Students practice to explore their feelings, memories and thoughts from an observer perspective [88]. Kohtala, Muotka and Lappalainen [89] showed in their study that acceptance of thoughts and feelings combined with mindful action had long-term effects on their subjective wellbeing. This shift in perspective may also increase self-compassion, which is a central part of the course. Selfcompassion is very important aspects effecting well-being since it has been shown to reduce stress, burnout and increase positive wellbeing $[90,91,92,93]$.

In this course, students also reflect and practice their ways of learning and studying. The time management task is used to help students to develop their studying by helping them to improve 
their time-management skills, setting goals and to allocate time to important things in life. Time and effort management has been shown to be related to better well-being $[11,34]$ and has been shown to be very important in managing studies in higher education $[61,62]$. Students also practice study techniques which support deeper understanding in their studying. Processes of understanding have been shown to be related to better well-being in higher education [11] and also better achievement in studies [57,58]. Furthermore, we argue that practicing ACT-based skills improve students' ability to concentrate and focus on studying as it has been shown that psychological flexibility is related to better progression in studies [46, 47].

The role of peer support is significant during this intervention course and it is used as a pedagogical tool to foster the development of psychological flexibility. In many studies, peer support has been shown to be very important in learning and studying [52, 56, 57]. Mead et al [55] have stated that peer support provides help through mutual respect and encouragement. The peer feedback instructions in this course are phrased so that students are to give each other encouraging and positive feedback and express if they relate to each other's experiences. This written, encouraging feedback from peers is used to enhance the learning of both the reviewers and the authors, to deepen their thinking, and to foster their reflection $[56,64]$. In addition, shared experiences with peers give emotional support and can have multiple positive effects on well-being [55, 94]. For this reason, we implemented group work and discussion to the course.

The other pedagogical tool during this intervention course is reflection, which is implemented through the course. Thus, this course includes reflective practices and they are included to foster students learning and to gain better learning outcomes, and to help students to reflect on their beliefs, feelings and emotions [75, 76, 77, 78].Reflective reports and reflective journal are tools to help students to monitor themselves and to get a holistic understanding of their thoughts, feelings, 
and practices, and further, to change their mode of action in cases in which they are harmful to them. These in turn are essential processes in fostering psychological flexibility [22,23]. The aim of reflective reports is to deepen students learning and processing the themes which were dealt with during the course $[76,78]$. Reflection is also practiced in small groups during this course. The group is essential because it helps students to comprehend someone else's situation empathically through the shared experiences and find a connection with each other which is important to foster their well-being [70]. Finally, during this course students are encouraged to take action in line with what is important to them, which is a core process in psychological flexibility; to strengthen one's value-based action $[83,88]$.

\section{Conclusion}

To sum up, our course aims to foster students' well-being by enhancing their psychological flexibility as well as their study-skills during the intervention. Recently brief social-psychological interventions have been called for, as mechanisms to improve academic performance [51]. Our intervention tool is a good example of a holistic approach to support studying at the university. Supporting both student well-being and their learning and studying skills can be regarded as a good way to support university students $[95,96]$. Focusing on clarifying one's values, to enhance one's value-based actions, being mindfully present and learning a new perspective towards one's thoughts are the most important processes which are practiced during the intervention.

\section{References}


1. Andrews, A.; Chong, J. L.Y. (2011). Exploring the wellbeing of students studying at an Australian University. Journal of the Australian and New Zealand Student Services Association.

2011, 37, 9- 38 .

2. Auerbach, R. P.; Mortier, P.; Bruffaerts, R.; Alonso, J.; Benjet, C.; Cuijpers, P.; Demyttenaere, K.; Ebert, D. D.; Green, J. G.; Hasking, P.; Murray, E.; Nock, M. K.; Pinder-Amaker, S.;

Sampson, N. A.; Stein, D. J.; Vilagut, G.; Zaslavsky, A. M.; Kessler, R. C.; WHO WMH-ICS Collaborators. WHO World Mental Health Surveys International College Student Project: Prevalence and distribution of mental disorders. J. Abnorm. Psychol., 2018, 127(7), 623-638. https://doi.org/10.1037/abn0000362

3. Pistorello, J. (Eds.). Mindfulness \& Acceptance for counselling college students. Theory and Practical Applications For Intervention, Prevention and Outreach. New Harbinger Publications, CA, United States, 2012.

4. American College Health Association (ACHA). ACHA-National College Health Assessment II: Reference group executive summary Spring 2011. Hanover, MD: American College Health Association, 2011.

5. Kunttu, K.; Pesonen, T. Student Health Survey 2013: a national survey among Finnish university students. Finnish Student Health Service studies, 2013, 47.

6. European Commission. Dropout and completion in higher education in Europe main report. Luxembourg: Author. 2015.

7. Conley, C. S.; Kirsch, A. C.; Dickson, D. A.; Bryant, F. B. Negotiating the transition to college: Developmental trajectories and gender differences in psychological functioning, 
cognitive-affective strategies, and social wellbeing. Emerg. Adulthood, 2014, 2(3), 195-210 https://doi.org/10.1177/2167696814521808

8. Kerig, P.K.; Schulz, M.S. The transition from adolescence to adulthood: What lies beneath and what lies beyond. In Adolescence and beyond: Family processes and development; Kerig, P.K., Schulz, M.S., Hauser, S.T., Eds.; Oxford University Press, Inc., New York, NY, 2012; pp. $3-12$.

9. Salmela-Aro, K.; Read, S. Study engagement and burnout profiles among Finnish higher education students. Burn. Res., 2017, 7, 21-28. doi:https://doi.org/10.1016/j.burn.2017.11.001

10. Durlak, J.A.; Weissberg, R.P.; Dymnicki, A.B.; Taylor, R.D.; Schellinger, K.B. The impact of enhancing students? social and emotional learning: A meta-analysis of school-based universal interventions. Child Dev., 2011, 82(1), 405-432.

11. Asikainen, H.; Salmela-Aro, K.; Parpala, A.; Katajavuori, N. (2019). Learning profiles and their relation to study-related burnout and academic achievement among university students. Learning and Individual differences, 2019, 78. DOI: 10.1016/j.lindif.2019.101781

12. Nieminen, J.; Lindblom-Ylänne, S.; Lonka, K. The development of study orientations and study success in students of pharmacy. Instr. Sci., 2004, 32(5), 387-417.

13. Asikainen, H.; Parpala, A.; Virtanen, V.; Lindblom-Ylanne, S. The relationship between student learning process, study success and the nature of assessment. A qualitative study. Stud. Educ. Evaluation, 2013, 39 (4), 211-217. 
14. Postareff, L.; Mattsson, M.; Lindblom-Ylänne, S.; Hailikari, T. The complex relationship between emotions, approaches to learning, study success and study progress during the transition to university. High. Educ., 2017, (73),441-457.

15. Dodge, R., Daly, A., Huyton, J., \& Sanders, L. The challenge of defining wellbeing. International Journal of Wellbeing, 2012, 2(3), 222-235. doi:10.5502/ijw.v2i3.4

\section{WORDL HEATH oRGANISATION}

17. Ryan, R. M., \& Deci, E. L. On happiness and human potentials: A review of research on hedonic and eudaimonic well-being. Annual Review of Psychology, 2001, 52, 141-166.

18 Keyes, C. L. M., Shmotkin, D., \& Ryff, C. D. Optimizing well-being: The empirical encounter of two traditions. Journal of Personality and Social Psychology, 2002, 82(6), 10071022. https://doi.org/10.1037/0022-3514.82.6.1007

19. Ryff, C.D. Happiness is everything, or is it? Explorations on the meaning of psychological wellbeing. Journal of Personality and Social Psychology, 1989, 57, 1069-1081.

20 Keyes , C. (1998) Social Well-Being. Social Psychology Quarterly, 1998, Vol. 61, No. 2 pp. $121-140$

21. Bond, F.; Joda, L.; Guenole, N. The work-related acceptance and action questionnaire (WAAQ): Initial psychometric findings and their implications for measuring psychological flexibility in specific contexts. J. Occup. Organ. Psychol., 2013, 86 (3), 331-347.

22. Hayes, S. Acceptance and commitment therapy: towards a unified model of behavior change. World Psychiatry : Official Journal of the World Psychiatric Association, 2019, 18 (2), 226-227. DOI: $10.1002 /$ wps.20626 
23. Hayes, S.; Luoma, J.; Bond, F.; Masuda, A.; Lillis, J. Acceptance and commitment therapy: Model, processes, and outcomes. Behav. Res. Ther., 2006, 44 (1), 1-25.

24. Chawla, N.; Ostafin, B. Experiential avoidance as a functional dimensional approach to psychopathology: An empirical review. J. Clin. Psychol., 2007, 63 (9), 871-890.

25 Hayes, S.; Hoffman, S. The third wave of cognitive behavioral therapy and the rise of process-based care. World Psychiatry, 2013, 16 (3), 245-246.

26. Hayes, S.C.; Pistorello, J.; Levin, M.E. Acceptance and commitment therapy as a unified model of behavior change. Couns. Psychol., 2012, 40, 976-1002.

27. Kashdan, T.; Barrios, V.; Forsyth, J.; Steger, M. Experiential avoidance as a generalized psychological vulnerability: Comparisons with coping and emotion regulation strategies. Behav. Res. Ther., 2006, 44, 1301-1320

28. Bond, F.W.; Flaxman, P.E.; van Veldhoven, M.J.P.M.; Biron, M. The impact of psychological flexibility and acceptance and commitment therapy (ACT) on health and productivity at work. In Contemporary occupational health psychology: Global perspectives on research, education, and practice; Houdmont, J.; Leka, S.; Eds. Wiley-Blackwell, Chichester, UK, 2010, pp. 296-313.

29. Hacker, T.; Stone, P.; Macbeth, A. Acceptance and commitment therapy - Do we know enough? Cumulative and sequential meta-analyses of randomized controlled trials. J. Affect. Disord., 2015, 15(190), 551-565 
30. Luoma, J.; Hayes, S. Cognitive defusion. In Cognitive behavior therapy: Applying empirically supported techniques in your practice, 2nd ed.; O'Donohue, W.T., Fisher J.E., Eds.; John Wiley \& Sons Inc., Hoboken, NJ, USA, 2008, pp. 83-90

31. Räsänen, P.; Lappalainen, P.; Muotka, J.; Tolvanen, A.; Lappalainen, R. An online guided ACT intervention for enhancing the psychological wellbeing of university students: A randomized controlled clinical trial. Behav. Res. Ther., 2016, 78, 30-42.

32. Kato, T. Impact of psychological inflexibility on depressive symptoms and sleep difficulty in a Japanese sample. SpringerPlus 5, 2016, 712. https://doi.org/10.1186/s40064-016-2393-0

33. Masuda, A., Price, M., Anderson, P. L., \& Wendell, J. W. Disordered Eating-Related Cognition and Psychological Flexibility as Predictors of Psychological Health Among College Students. Behavior Modification, 2010, 34(1), 3-15.

34. Kashdan, T.B., \& Rottenberg, J., Psychological flexibility as a fundamental aspect of health, Clinical Psychology Review, 2010, 30(7):865-78.

35. Sheldon, K. M., Cummins, R., \& Khamble, S. Life-balance and well-being: Testing a twopronged conceptual and measurement approach. Journal of Personality, 2010, 78, 1093-1134

36. Ruiz, F. A review of Acceptance and Commitment Therapy (ACT) empirical evidence: Correlational, experimental psychopathology, component and outcome studies. Int. J. Psychol. Psychol. Ther., 2010, 10 (1), 125-162

37. French, K.; Kolijani-Moghaddam, N.; Schröder, P. What is the evidence for the efficacy of self-help acceptance and commitment therapy? A systematic review and meta-analysis. $J$. Contextual Behav. Sci., 2017, 6 (4), 360-374. 
38. Viskovich, S.; Pakenham, K.I. Pilot evaluation of a web-based acceptance and commitment therapy program to promote mental health skills in university students. J. Clin. Psychol., 2018, 74 (12), 2047-2069

39. Hacker, T.; Stone, P.; MacBeth, A. Acceptance and commitment therapy-do we know enough? Cumulative and sequential meta-analyses of randomized controlled trials. J. Affect. Disord. 2016, 190, 551-565, 10.1016/j.jad.2015.10.053

40. Dimidjian, S.; Arch, J.J.; Schneider, R.L.; Desormeau, P.; Felder, J.N.; Segal Z.V. Considering meta-analysis, meaning, and metaphor: A systematic review and critical examination of "third wave" cognitive and behavioral therapies. Behav. Ther., 2016, 47, 886905. 10.1016/j.beth.2016.07.002

41. Flaxman, P.; Bond, F.; Livheim, F.; Hayes, S. (Eds.). The mindful and effective employee: An acceptance and commitment therapy training manual for improving well-being and performance. Oakland: New Harbinger Publishers, 2013.

42. Puolakanaho, A.; Tolvanen, A.; Kinnunen, S.; Lappalainen, R. A psychological flexibility based intervention for Burnout: A randomized controlled trial. J. Contextual Behav. Sci., 2020, $15,52-67$.

43. Danitz, S.B.; Orsillo, S.M. The Mindful Way Through the Semester: An Investigation of the Effectiveness of an Acceptance-Based Behavioral Therapy Program on Psychological Wellness in First-Year Students. Behav. Modif., 2014, 38, (4), 549-566.

https://doi.org/10.1177/0145445513520218 
44. Levin, M. E.; Haeger, J.A.; Pierce, B.G.; Twohig, M.P. Web-based acceptance and commitment therapy for mental health problems in college students: A randomized controlled trial. Behav. Modif., 2017, 41(1), 141-162. doi://dx.doi.org/10.1177/0145445516659645

45. Howell, A.; Passmore, H. Acceptance and Commitment Training (ACT) as a Positive Psychological Intervention: A Systematic Review and Initial Meta-analysis Regarding ACT's Role in Well-Being Promotion Among University Students. J. Happiness Stud., 2018, 1-16.

46. Asikainen, H.; Hailikari, T.; Mattsson, M. The interplay between academic emotions, psychological flexibility and self-regulation as predictors of academic achievement. J. Furth. High. Educ., 2017, 1-15. doi:10.1080/0309877X.2017.1281889

47. Asikainen, H. Examining indicators for effective studying - the interplay between student integration, psychological flexibility and self-regulation in learning. Psychol. Soc. Educ., 2018, $10(2), 225-237$.

48. Dionne, F. Using acceptance and mindfulness to reduce procrastination among university students: Results from a pilot study. Revista Prâksis, 2016, 1, 8-20.

49. Gagnon, J.; Dionne, F.; Pychyl, T.A. Committed action: An initial study on its association to procrastination in academic settings. J. Contextual Behav. Sci., 2016, 5 (2), 97-102.

50. Eisenbeck, N.; Carrenob, D.F.; Uclés Juárezb, U.

From psychological distress to academic procrastination: Exploring the role of psychological infl exibility. J. Contextual Behav. Sci. 2019, 13:103-108 
51. Jeffords, J.R.; Bayly, B.L.; Bumpus, M.F.; Hill, L.G. Investigating the Relationship Between University Students' Psychological Flexibility and College Self-Efficacy. J. Coll. Stud. Ret., 2018, 1-22, https://doi.org/10.1177/1521025117751071

52. Lonka, K.; Olkinuora, E.; Mäkinen, J. Aspects and prospects of measuring studying and learning in higher education. Educ. Psychol. Rev., 2004, 16 (4), 301-323. doi:10.1007/s10648004-0002-1

53. Asikainen, H.; Gijbels, D. Do students develop towards more deep approaches to learning during studies? A systematic review on the development of students' deep and surface approaches to learning in higher education. Educ. Psychol. Rev., 2017, 29(2), 205-234. doi:10.1007/s10648-017-9406-6

54. Marton, F.; Säljö, R. Approaches to learning. In The experience of learning, Marton, F., Hounsell, D., Entwistle, N.; Eds., Edinburgh: Scottish Academic Press, 1984, pp. 36-55.

55. Vanthournout, G.; Donche, V.; Gijbels, D.; Van Petegem, P. (Dis)similarities in research on learning approaches and learning patterns. In Learning patterns in higher education: dimensions and research perspectives, Gijbels, I.D., Donche, V., Richardson, J.T.E., Vermunt, J.D.; Eds., New York: Routledge., 2014, pp. 11-32.

56. Entwistle, N. J.; Peterson, E.R. Conceptions of learning and knowledge in higher education: Relationships with study behaviour and influences of learning environments. Int. J. Educ. Res., 2004, 41, 407-428. doi:10.1016/j.ijer.2005.08.009.

57. Diseth, Å.; Martinsen, Ø. Approaches to Learning, Cognitive Style, and Motives as Predictors of Academic Achievement. Educ. Psychol. 2003, 23 (2), 195. 
58. Watters, D.; Watters, J. Approaches to Learning by Students in the Biological Sciences: Implications for teaching. Int. J. Sci. Educ. 2007, 29:1, 19-43, DOI:

$10.1080 / 09500690600621282$

59. Ruohoniemi, M.; Parpala, A.; Lindblom-Ylänne, S.; Katajavuori, N. Relationships Between Students' Approaches to Learning, Perceptions of the Teaching-Learning Environment, and Study Success: A Case Study of Third-Year Veterinary Students. J. Vet. Med. Educ. 2010, 37 (3), 282-288.

60. Asikainen, H.; Parpala, A.; Lindblom-Ylänne, S.; Vanthournout, G.; Coertjens, L. The development of approaches to learning and perceptions of the teaching-learning environment during bachelor level studies and their relation to study success. High. Educ. Stud. 2014, 4 (4), 24-36.

61. Hailikari, T.; Parpala, A. What impedes or enhances my studying? The interaction between approaches to learning, factors influencing study progress and earned credits. Teach. High.

Educ., 2014, 19 (7), 812-824. doi:10.1080/13562517.2014.934348.

62. Rytkönen, H.; Parpala, A.; Lindblom-Ylänne, S.; Virtanen, V.; Postareff, L. Factors affecting bioscience students' academic achievement. Instr. Sci., 2012, 40(2): 241-56.

63. Häfner, A.; Oberst, V.; Stock, A. Avoiding procrastination through time management: An experimental intervention study. Educ. Stud., 2014, 40 (3), 352-360.

https://doi.org/10.1080/03055698.2014.899487 
64. Glick, D. M., Millstein, D. J., \& Orsillo, S. M. A preliminary investigation of the role of psychological inflexibility in academic procrastination. Journal of Contextual Behavioral Science, 2014, 3(2), 81-88.

65. Barak, A.; Hen, L.; Boniel-Nissim, M.; Shapira, N. A Comprehensive Review and a MetaAnalysis of the Effectiveness of Internet-Based Psychotherapeutic Interventions. J. Technol. Hum. Serv., 2008, 26 (2-4): 109-160.

66. Barrable, A.; Papadatou-Pastou, M.; Tzotzoli, P. Supporting mental health, wellbeing and study skills in Higher Education: an online intervention system. Int. J. Ment. Health Syst., 2018, 12, Article number: 54.

67. Muto, T.; Hayes, S.C.; Jeffcoat, T. The effectiveness of acceptance and commitment therapy bibliotherapy for enhancing the psychological health of japanese college students living abroad. Behav. Ther., 2011, 42 (2), 323-335. doi://dx.doi.org/10.1016/j.beth.2010.08.009

68. Beckert, L.; Wilkinson, T.; Sainsbury, R. A needs-based study and examination skills course improves students' performance. Med. Educ., 2003, 37 (5), 424-428

69. Pryjmachuk, S.; Gill, A.; Wood, P.; Olleveant, N.; Keeley,N. Evaluation of an online study skills course. Act. Learn. High. Educ., 2012, 13 (2),155-168.

https://doi.org/10.1177/1469787412441298.

70. Topping, K.J. Using peer assessment to inspire reflection and learning. Routledge, New York, 2018. 
71. Parpala, A.; Lindblom-Ylänne, S.; Komulainen, E.; Entwistle, N. Assessing students’ experiences of teaching-learning environments and approaches to learning: Validation of a questionnaire used in different countries and varying contexts. Learn. Environ. Res., 2013, 16 (2), 201-215. http://dx.doi.org/ 10.1007/s10984-013-9128-8

72. Mead, S.; Hilton D.; Curtis, L. Peer support: A theoretical perspective. Psychiatr. Rehabil. J., 2001, 25, 134-141.

73. Drum D.J.; Brownson C.; Denmark A.B.; Smith S.E. New data on the nature of suicidal crises in college students: Shifting the paradigm. Prof. Psychol. Res. Pr., 2009, 40 (3), 213-222.

74. Dennis, C-L. Peer support within a health care context: a concept analysis. International Journal of Nursing Studies, 2003, 40(3), 321-332.

75. Nelson Laird, T.F.; Seifert, T.A.; Pascarella, E.T.; Mayhew, M.J.; Blaich. C.F. "Deeply Affecting First-Year Students' Thinking: Deep Approaches to Learning and Three Dimensions of Cognitive Development." J. High. Educ., 2014, 85 (3): 402-32

76. Moon, J. A handbook of reflective practice and experiential learning: Theory and practice. Routledge Falmer, London, 2004.

77. Larrivee, B. Development of a tool to assess teachers' level of reflective practice. Reflective Pract., 2008, 9 (3), 341-360.

78. Harvey, M.; Coulson, D.; McMaugh, A. Towards a theory of the ecology of reflection: Reflective practice for experiential learning in higher education. J. Univ. Teach. Learn. Pract., 2016, 13(2). Retrieved from http://ro.uow.edu.au/jutlp/vol13/iss2/2 
79. Kreber, C.; Castleden, H. Reflection on teaching and epistemological structure: Reflective and critically reflective process in "pure/soft" and "pure/hard" fields. High. Educ., 2009, 57 (4), 509-531.

80. Mezirow, J. Transformative learning as discourse. J. Transform. Educ., 2003, 1(1), 58-63.

81. Quinton, S.; Smallbone, T. Feeding forward: using feedback to promote student reflection and learning - a teaching model. Innov. Educ. Teach. Int., 2010, 47 (1), 125-135. https://doi.org/10.1080/14703290903525911

82. Grégoire, S.; Lachance, Li.; Bouffard, T.; Dionne, F. The Use of Acceptance and Commitment Therapy to Promote Mental Health and School Engagement in University Students: A Multisite Randomized Controlled Trial. Behav. Ther., 2018, 49 (3), 360-372

83. LeJeune, J.; Luoma, J.B. Values in Therapy: A Clinician's Guide to Helping Clients Explore Values, Increase Psychological Flexibility, and Live a More Meaningful Life. New Harbinger Publications, Oakland, CA, 2019.

84. Allison, S.; Irwin Hamilton, K.; Yuan, Y.; Wallis Hague G. Assessment of Progressive Muscle Relaxation (PMR) as a Stress-Reducing Technique for First-Year Veterinary Students. Journal of Veterinary Medical Education, 2019. https://doi.org/10.3138/jvme.2018-0013

85 Matzer, F., Nagele, E., Lerch, N., Vajda, C., Fazekas, C. Combining walking and relaxation for stress reduction - A randomized cross-over trial in healthy adults. Stress \& Health, 2018, 34 (2): 266-277. 
86. Sherikar, A. \& Kulkarni, N.S. Effect of group based mindful meditation versus progressive muscle relaxation on stress in post modified radical mastectomy patients. International Journal of Scientific Research, 2019, 8(7), 1-3.

87. Ruiz, F.J. Acceptance and Commitment Therapy versus Traditional Cognitive Behavioral Therapy: A Systematic Review and Meta-analysis of Current Empirical Evidence. International Journal of Psychology \& Psychological Therapy, 2012, 12, 2, 333-357.

88. Hayes, S.; Stroshal, K.; Wilson, K. Acceptance and Comitment Therapy: The Process and Practice of Mindful Change, 2nd ed. Guilford Press; New York., 2012.

89. Kohtala, A.; Muotka, J.; Lappalainen, R. Changes in Mindfulness Facets and Psychological Flexibility Associated with Changes in Depressive Symptoms in a Brief Acceptance and Value Based Intervention: An Exploratory Study. International Journal of Psychology and Psychological Therapy, 2018, 18 (1), 83-98

90. Stutts, L, Leary, M., Zeveney, A., Hufnagle A. A longitudinal analysis of the relationship between self-compassion and the psychological effects of perceived stress. Journal of Self and Identity, 2018, 17 (6): 609-626. https://doi.org/10.1080/15298868.2017.1422537

91. Bluth, K., Roberson, P., Gaylord, S. A Pilot Study of a Mindfulness Intervention for Adolescents and the Potential Role of Self-Compassion in Reducing Stress. Explore, 2015, 11 (4): 292-295.https://doi.org/10.1016/j.explore.2015.04.005

92. Durkin, M., Beaumont, E., Hollins Martin, C., Carson, J. A pilot study exploring the relationship between self-compassion, self-judgement, self-kindness, compassion, professional 
quality of life and wellbeing among UK community nurses. Nurse Education Today, 2016, 46: $109-114$.

93. Neff, K.D. Self-compassion: An alternative conceptualization of a healthy attitude toward oneself. Self Identity, 2003, 2 (2), 85-101. 10.1080/15298860309032

94. Berk L, Warmenhoven F, Stiekema, APM, van Oorsouw, K., van Os, J., de Vugt M. \& van Boxtel, M. Mindfulness-Based Intervention for People With Dementia and Their Partners: Results of a Mixed-Methods Study. Front. Aging Neurosci., 2019, 11:92. doi: 10.3389/fnagi.2019.00092

95. Asikainen, H., Kaipainen, K., \& Katajavuori, N. Understanding and promoting students' well-being and performance in university studies, J. Univ. Teach. \& Learn. Prac., 2019, 16(5), $1-15$.

96. Barrable, A., Papadatou-Pastou, M. \& Tzotzoli, P. Supporting mental health, wellbeing and study skills in Higher Education: an online intervention system. Int J Ment Health Syst 12, 54 (2018). https://doi.org/10.1186/s13033-018-0233-Z

\section{Ethics approval and consent to participate}

This study has been conducted following the guidelines prepared by the National Advisory Board on Research Ethics entitled "Good scientific practice and procedures for handling misconduct and fraud in science"

\section{Consent for publication}

Both authors gives their consent to publication

\section{Availability of data and materials}

This case-study has been conducted without data. 


\section{Competing interests}

No competing interests

\section{Funding}

No additional funding has been used

\section{Authors' contributions}

The authors have equally contributed

\section{Acknowledgements}




\section{Figures}

\section{Impact of the course}

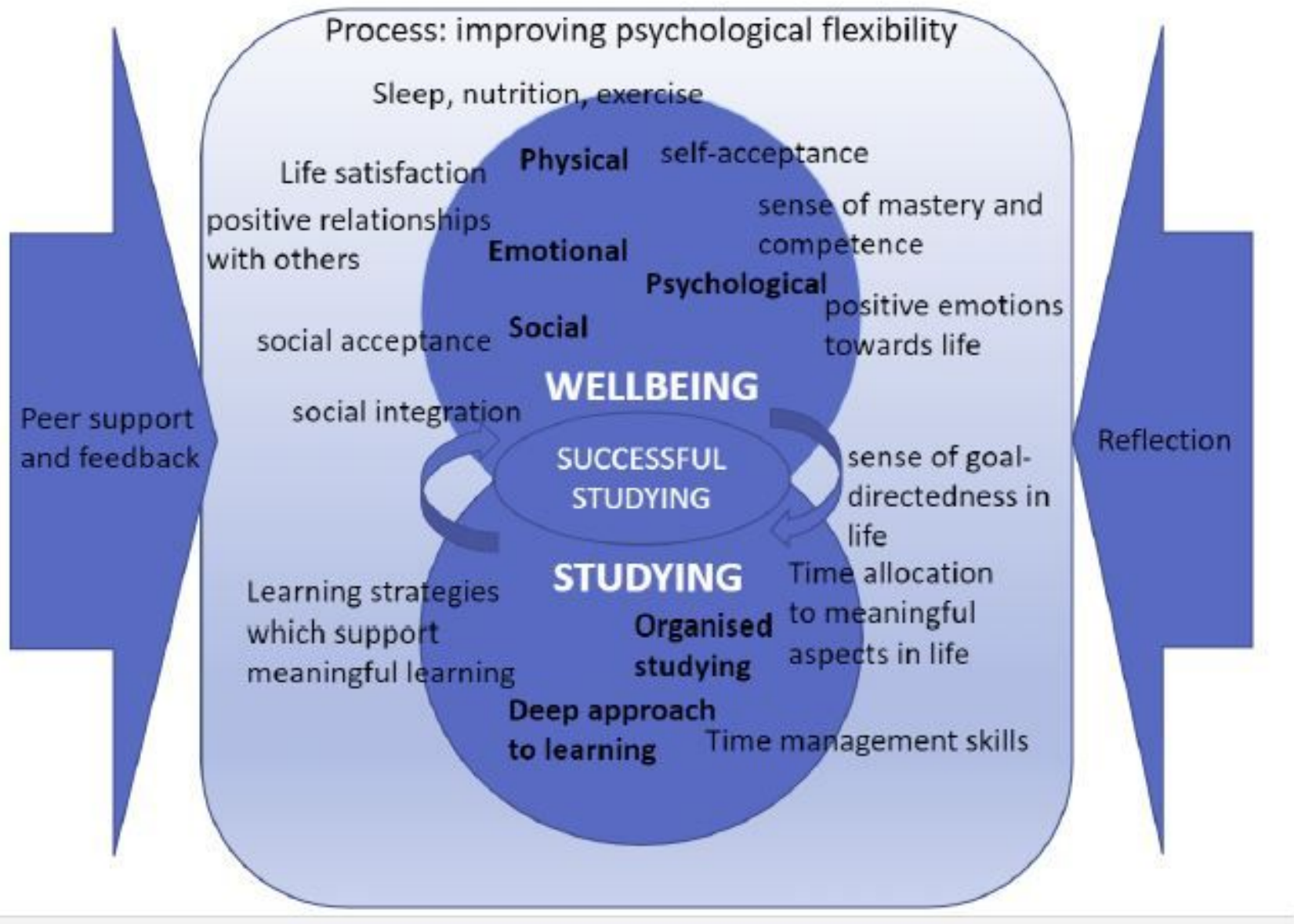

\section{Figure 1}

Impact of the course

\begin{tabular}{|c|c|c|c|c|c|c|c|}
\hline $\begin{array}{l}\text { Introduction } \\
\text { Module }\end{array}$ & Module 1 & Module 2 & Module 3 & Module 4 & Module 5 & Module 6 & Module 7 \\
\hline $\begin{array}{l}\text { Introduction } \\
\text { to the course } \\
\text { and themes }\end{array}$ & $\begin{array}{l}\text { THEME } \\
\text { What is } \\
\text { important: }\end{array}$ & $\begin{array}{l}\text { THEME } \\
\text { Focusing on } \\
\text { the present: }\end{array}$ & $\begin{array}{l}\text { THEME } \\
\text { Power of } \\
\text { thoughts : }\end{array}$ & $\begin{array}{c}\text { THEME } \\
\text { Coping with } \\
\text { studving. }\end{array}$ & $\begin{array}{l}\text { THEME } \\
\text { Acceptance } \\
\text { and self- }\end{array}$ & $\begin{array}{l}\text { THEME } \\
\text { Acceptance } \\
\text { and self- }\end{array}$ & $\begin{array}{c}\text { Evaluation of } \\
\text { wellbeing and } \\
\text { studying }\end{array}$ \\
\hline $\begin{array}{c}\text { Evaluation of } \\
\text { wellbeing and } \\
\text { studying }\end{array}$ & $\begin{array}{l}\text { Individual } \\
\text { assignments, } \\
\text { setting a goal }\end{array}$ & $\begin{array}{c}\text { Individual } \\
\text { assignments }\end{array}$ & $\begin{array}{c}\text { Individual } \\
\text { assignments }+ \\
\text { online meeting }\end{array}$ & $\begin{array}{l}\text { Individual } \\
\text { assignments }\end{array}$ & $\begin{array}{l}\text { Individual } \\
\text { assignments }\end{array}$ & $\begin{array}{l}\text { compassion: } \\
\text { Individual } \\
\text { assignments }\end{array}$ & $\begin{array}{c}\text { report }+ \\
\text { individual } \\
\text { feedback from } \\
\text { peers }\end{array}$ \\
\hline $\begin{array}{l}\text { Start of peer } \\
\text { group work }\end{array}$ & $\begin{array}{c}\text { Group } \\
\text { discussion and } \\
\text { reflection }\end{array}$ & $\begin{array}{l}\text { Group } \\
\text { discussion and } \\
\text { reflection }\end{array}$ & $\begin{array}{l}\text { Group } \\
\text { discussion and } \\
\text { reflection }\end{array}$ & $\begin{array}{c}\text { Group } \\
\text { reflection } \\
\text { assignment }\end{array}$ & $\begin{array}{c}\text { Group } \\
\text { discussion and } \\
\text { feedback }\end{array}$ & $\begin{array}{l}\text { Group } \\
\text { discussion and } \\
\text { reflection }\end{array}$ & $\begin{array}{l}\text { Group } \\
\text { discussion and } \\
\text { reflection }\end{array}$ \\
\hline \multicolumn{8}{|c|}{ REFLECTION } \\
\hline
\end{tabular}


Design of the course 